DOI: 10.2478/ausfm-2021-0001

\title{
Screening Landscapes: Film between the Picturesque and the Painterly
}

\author{
Steven Jacobs \\ Ghent University (Belgium) \\ E-mail: Steven.Jacobs@ugent.be
}

\begin{abstract}
Inherently connected to movement and to a sequential spatial experience in time, the picturesque has been considered as a precursor of the cinematic. In addition, the idea of the picturesque is closely connected to Heinrich Wölfflin's notion of das Malerische or "the painterly," which stands for a dynamic style of painting characterized by qualities of colour, stroke, and texture rather than of contour or line. Based on the keynote lecture delivered at the conference, The Picturesque: Visual Pleasure and Intermediality in-between Contemporary Cinema, Art and Digital Culture (Sapientia Hungarian University of Transylvania, 25-26 October, 2019), ${ }^{1}$ the essay disentangles the complex network of connections between image and landscape, painting and film, the picturesque and the painterly.
\end{abstract}

Keywords: picturesque, photoresque, painting and film, stillness and movement in film.

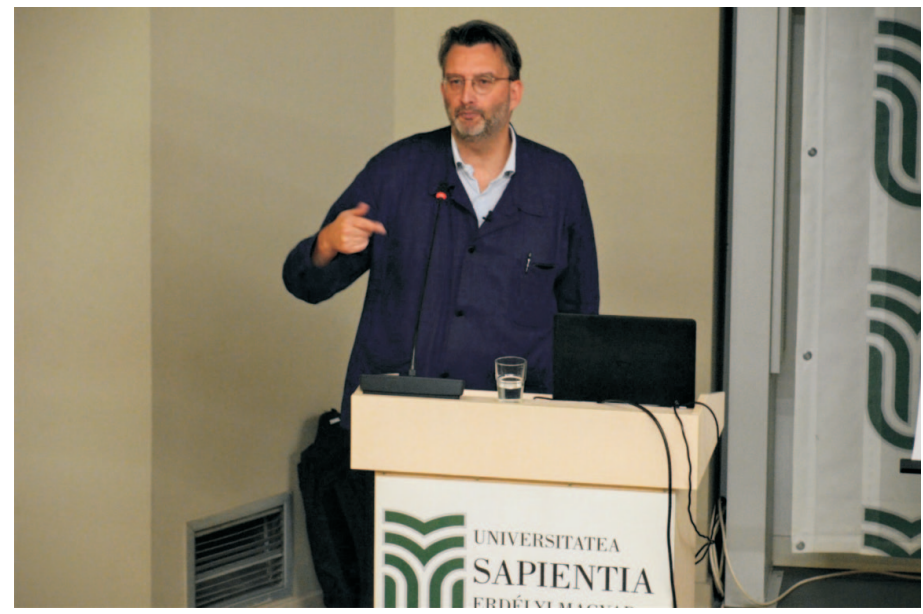

Steven Jacobs at the conference (Photo by Mira Marincaş, 26 October, 2019.)

1 Video recording of the keynote lecture here: https://youtu.be/ipLo4-hixKk?list=PLDesrDcatwba GiIK2Fkg3gH44hIDp6P4H. Last accessed 12. 12. 2020. 


\section{From the Picturesque to the Photoresque}

The aesthetics of the picturesque, which developed in the eighteenth century in close relation with new ideas and practices of gardening, exchanged the preference for the geometry of French gardens for a predilection for the whimsicality of nature (Hussey 1927; Tobey 1973, 128-135; Hunt 1976 and 1994; Hunt and Willis 1988, and Macarthur 2007). However, rather than favouring the irregularity of nature itself, the picturesque was first and foremost inspired by the image of nature's whimsicality and irregularity. In the aesthetics of the picturesque, nature is approached indirectly, through pictures - through the paintings of Claude Lorrain, Nicolas Poussin, Salvator Rosa, Meindert Hobbema, and Jacob van Ruisdael, for instance. This implied that, on the one hand, English landscape gardens were designed to be viewed as a Lorrain or a Poussin might paint them - trees were replanted, rivers and hills were moved, fake ruins, grottoes, and follies were built so that the landscape answered to the conventions of pictorial composition. On the other hand, viewers were enticed to discover and recognize picturesque scenes in nature itself. Publishing his Three Essays in 1792, William Gilpin, for instance, encouraged tourists "to frame views, to graduate prospects from foreground to background, and above all, to ensure variety of painted, drawn, or engraved texture, which minimized similar qualities in the natural world" (Gilpin quoted in Hunt 1991, 236). Furthermore, many travellers looked at the landscape with the help of a so-called Claude glass, an often oval-shaped, black convex mirror, making the landscape more "pictorial” (Maillet 2004).

This interconnection between the image of the landscape and its referent is included in the notion of landscape itself, which, according to the Oxford English Dictionary, occurred for the first time in 1603 and was borrowed from the Dutch landschap, probably because of the importance of landscape painting from Flanders and the Netherlands. In Dutch, like in many other languages, the word had from the very first the double meaning of both a "piece of land" and an "image" representing such a piece of land: landschap, landscape, Landschaft, paysage, paesaggio, et cetera (Kolen and Lemaire 1999, 11-26). This double meaning emphasizes that the notion of landscape has been, from the very first, dependent on its structuring by human presence and by the gaze in particular. The experience and the representation of the landscape are closely connected. Several scholars, including art historian Ernst Gombrich, who often emphasized the role of mental concepts in perception, even argue that the art of painting made possible the aesthetic experience of the environment as a landscape (Smuda 1986, 64-65; Howett 1997, 86-87). 
Inspired by a modernist self-referentiality or a post-structuralist attempt at deconstruction, many modern and contemporary artists visualizing landscapes explicitly and implicitly play on this tension. Leading artists and photographers such as Robert Smithson, Mark Klett, Joel Sternfeld, Jeff Wall, Andreas Gursky, and Axel Hütte, for instance, have visualized today's posturban landscape, in which the differences between centre and periphery, city and country, and culture and nature are no longer clearly defined. These artists focus on natural landscapes that are marked by the paraphernalia of traffic or tourist infrastructures, while also referring to older pictorial conventions of landscape representations (Jacobs 2009, 23-64; Jacobs 2012). Frequently evoking conventional representations of the landscape by referring to "classical" Arcadian myths, the Romantic sublime, or the picturesque, these artists turn photography into a medium that appropriates, emulates, or deconstructs pictorial representations of landscapes.

\section{The Picturesque and Cinema}

Many instances of such a picturesque strategy can be found in the history of cinema. Since cinema's inception, filmmakers have looked at nature through earlier pictorial or graphic landscape representations. Early scenics and travelogues, Scandinavian or Italian feature films of the 1910s, and directors such as Murnau and John Ford, to name just a few, are unmistakably indebted to nineteenth-century landscape painters, whose works can be situated in the tradition of the picturesque (Dalle Vacche 1996, Cowie 2004; Clarke and Doel 2006, 213-244; Bertellini 2009). Through the use of carefully selected lenses, viewpoints, framings, shot compositions, and light conditions, many filmmakers have created veritable cinematic equivalents of nineteenth-century landscape paintings. Sometimes, such references can be quite literal, such as in Peter Schamoni’s feature film Caspar David Friedrich: Grenzen der Zeit (1986), which can be considered a biopic dedicated to the famous German romantic landscape painter (Hoffmann 2003, 30-41; on artists' biopics, see Jacobs 2011, 38-62). However, the film is not an artist biopic in the strict sense, as its story is set after the death of the protagonist. In addition, the film lacks many other of the tropes of the genre, but consists first and foremost of footage of the nature in Pomerania, the Baltic coasts, and the island of Rügen - sites that inspired Friedrich. Evoking Friedrich's paintings, Schamoni's film offers us expansive vistas but also focuses on various natural phenomena such as clouds, water surfaces, and the play of light.

A notion closely connected to movement and atmospheric effects, the picturesque seems to lend itself easily to film as it has been described as a medium 
perfectly suited to evoke the ephemeral by various filmmakers and theorists such as Jean Epstein, Germaine Dulac, and Siegfried Kracauer. In addition, the idea of a series of successive framed views, as organized in picturesque gardens, has been described as "pre-cinematic" (McArthur 2007, 111, 156, 164, 249). The eighteenth-century picturesque came to be seen as a kind of pictoriality with movement added. Sergei Eisenstein too, as I will demonstrate in a following part, connected montage to the picturesque.

\section{Movement, Architecture, and Modern Space}

As the picturesque was associated with movement, it is also something that is connected to time and space, albeit in complex and even paradoxical ways. On the one hand, paintings represent spaces in which one can imagine moving. On the other, as material things in our "real" physical space, they have their own position as objects hung on the wall and they are related spatially to a mobile observer. Since the dominance of framed easel pictures, this viewing position has been a disembodied gaze. By contrast, our visual experience of gardens, buildings, and cities is as embodied subjects. A picturesque landscape oscillates between these two spatial registers.

Furthermore, inherently connected to movement, the picturesque is closely linked with stillness. The picturesque in architecture, gardening, and urbanism stills the viewer. Presenting the landscape as a picture, the aesthetics of the picturesque removes the particularity of viewing in motion and duration, flattening space. In so doing, picturesque gardening thwarts movement, breaking the pattern of successive topoi that characterized earlier allegorical gardens. Hence, the earliest attempt at an art of visual duration strikingly grew out of a concept of stillness. This relates to the fact that the literature of the eighteenth-century picturesque was not so much preoccupied with movement in the sense of motion of people through the landscape. Rather, under picturesque conditions, buildings appear to possess movement.

As John Macarthur has demonstrated, this concept of movement in architecture was further developed by Heinrich Wölfflin in his influential description of Baroque architecture, which was also inherently linked to the notion of the picturesque (Macarthur 2007, 240-247; Wölfflin 1999, Wölfflin 1888). For Wölfflin, movement in architecture is a matter of emphatic relations with the building, which have not to do with bodily movement or the body's capacity for spatial extension and locomotion. This harks back to theoreticians of the picturesque such as Uvedale Price, who stated that the movement of the eye is a kind of imitation of the form of the object, moving across it to follow its form. In Renaissance und Barock (1888), 
Wölfflin uses a distinction that is more or less similar with Price's ideas of the beautiful and picturesque in architecture. Whereas, for Wölfflin, Renaissance is the art of calm and beauty, the Baroque is a "painterly" style - "painterly" in the sense that it lends itself to being painted. Writing in German, Wölfflin uses the word malerisch, which can be translated as "painterly," "pictorial," and also "picturesque." Like the English term "picturesque," "malerisch" was regularly used in relation to landscape - for instance, in the writings by Schiller and Goethe. For Wölfflin, "a strictly classical temple, if not in ruins, is not a picturesque object. However impressive it may be as a piece of architecture, it would look monotonous in a picture. An artist painting it on a canvas would have great difficulty in making it look interesting; in fact he could only succeed with the aid of light and atmospheric effects and a landscape setting" (Wölfflin quoted in Macarthur 2007, 240). Likewise, baroque architecture is not only marked by massiveness, it is also characterized by movement. For Wölfflin, a rich baroque building is more animated, and would therefore be an easier subject for a painterly effect.

Wölfflin's use of the concept of the picturesque, which would highly determine its twentieth-century reception, was also connected to the notion of movement. However, as Wölfflin asserted, movement is not caused by the object; it is rather an innate mental power and the product of our perception of that object. Wölfflin was reluctant to connect this kind of movement to an actual locomotion in space. Like eighteenth-century theorists such as Uvedale Price or Joshua Reynolds, Wölfflin emphasized a pictorial concept of movement but he had no interest in connecting this with actual motion. This distinction or tension between visual movement and bodily stasis lies at the heart of the picturesque. Picturesque garden design is inherently connected to the principle that the eye can reach where the body cannot go. In picturesque garden designs, framings create distances, turning the landscape into a picture. Hence, movement is counterbalanced by an immobility. Furthermore, Wölfflin's idea of movement in buildings, sculptures, and paintings is marked by the influential psychological theory of Einfühlung that stipulated that we can be excited because our eyes move quickly over surfaces. The idea that picturesque or space connected to actual bodily movement was only developed by Wölfflin's contemporary August Schmarsow, who reflected on "das Malerische" (the picturesque or the painterly) in architecture and on Malerische Gesichtspunkte in der Baukunst (Picturesque Viewpoints in Architecture) in his 1897 Barock und Rokoko. In his writings, Schmarsow not only developed the idea of the picturesque in relation to architecture and space, he also linked it to the idea of movement as a kinaesthetic sensation. 
This idea of architecture as something that is perceived by movement as the experience of a spatial unfolding in time became fundamental in modern architectural theory. As John Macarthur noted, it was first and foremost developed by Wölfflin's student Sigfried Giedion in his seminal Space, Time, and Architecture (1941), in which he advocated architectural modernism polemically. Referring to new dynamic conceptions of space in modernist art movements such as cubism and Futurism as well as to Albert Einstein's physics, Giedion, like other protagonists of architectural modernism, saw architecture as something defined by volume of space rather than mass and solidity. Furthermore, for Giedion, movement became fundamental in his argument that modern architecture made space the proper medium of architecture. Space is something that is registered in locomotion and, hence, inherently connected to it.

Similar ideas can be found in the writings of László Moholy-Nagy and Sergei Eisenstein, who connected this dynamic conception of space to cinema. MoholyNagy, for instance, stated that "motion pictures, more than anything else, fulfill the requirements of a space-time visual art" $(1995,155)$. He also noted that modern sculpture and architecture had become "cinematic" as they became increasingly preoccupied with light and movement, evoking volumes that merge with their surrounding space as well as masses that dissolve into a spatial continuum. Modern sculpture and architecture tended, as it were, toward a kind of ephemeral, immaterial art of space akin to film.

According to Eisenstein, the mobile gaze of film was even developed or prepared in architecture, an art that implied real movement of the beholder in space instead of movement in its virtuality. At least potentially, because the cinematic character of architecture, based on sequentiality and montage, has long been repressed by architects. The art of cinema and montage, Eisenstein seems to argue, made architects aware of these features, which were rediscovered by Constructivist artists and architects such as Le Corbusier and his idea of the promenade architecturale. Eisenstein elaborated these ideas in an essay entitled Montage and Architecture, which he wrote in the late 1930s (see Eisenstein 1989, and the introduction to this essay written by Yve-Alain Bois). In that article, Eisenstein deals with the issue of montage computation within an architectural ensemble - something that he connects with the shifting point of view of a moving spectator. He contrasts two "paths" of the spatial eye: the cinematic, where a spectator follows an imaginary line among a series of objects; and the architectural, where the spectator moves "between [a series of] carefully disposed phenomena" $(1989,116)$. Eisenstein gives an example, and it is the Acropolis in Athens with its apparent disorder in the placement of buildings - a 
feature that racked the brain of so many architectural theorists working in the classical tradition. Eisenstein refers to Auguste Choisy's analysis of the Acropolis, which he cites at length. By means of a series of successive perspective views of the movement of an imaginary visitor of the Acropolis, Choisy (1903) demonstrated the successive tableaux and the "picturesque" composition of the site. In line with the writings by Uvedale Price, Choisy uses the word "picturesque" in his theory of urban planning as picturesqueness in regular buildings results from seeing them on incidental angles, avoiding frontality. Eisenstein asks his reader to look at Choisy's text "with the eye of a film-maker," to see it as a kind of perspectival "storyboard" of the Acropolis. "It's hard to imagine," Eisenstein writes, "a montage sequence for an architectural ensemble more subtly composed, shot by shot, than the one which our legs create by walking among the buildings of the Acropolis" (1989, 117). In Choisy's carefully sequenced perspectives, Eisenstein finds "a montage effect" and he even speculates on the desirable temporal duration of each picture, finding that the "shot length" can be determined by the relationship between the pace of the spectator's movement and the rhythm of the buildings themselves and the distances between each of them. He calls the Acropolis "the perfect example of one of the most ancient films" (1989, 117). For Eisenstein, picturesque planning was "cinematic." The picturesque can be interpreted as a form of what Eisenstein called "cinematism," meaning the presence of cinematic effects in various artworks predating the birth of film, and which he found in the Acropolis as well as in the art of El Greco, Piranesi, Japanese and Chinese scroll painters, Robert Delaunay, and the Mexican muralists (Montani 2000, 206-217; Jacobs 2016, 142-159). This led Eisenstein to numerous reflections about the inscription of time in a static picture and about the sequential nature of aesthetic perception.

Eisenstein's ideas were later developed by Yve-Alain Bois (1984), Peter Collins (1965), Richard Etlin (1987), and others, who advocated that the picturesque can be presented as the humble beginning of the idea that durational spatio-visual experience is a kind of material that can be formed in architecture, landscape, and urban design. As picturesque planning evokes motion, duration, and spatialized points-of-view, the idea of the picturesque became fulfilled in the technology and art of cinema, or in the cinematic understanding of the image in architecture.

\section{Paintscapes}

These dialectical relations between three-dimensional space and a series of twodimensional planes, between movement and stasis, and between durational development and stillness, are also at stake when the film camera confronts the 
landscape. In the following pages, however, I would like to take the idea of a "cinematic picturesque" back to its origins, investigating the encounter between the film camera and a landscape painting rather than dealing with films of natural landscapes themselves.

Some key art documentaries of the 1940s and 1950s, which can be considered the "Golden Age" of the art documentary (Jacobs 2011, 1-37), focus on landscape painting. This is the case in Alain Resnais's Van Gogh (1949), which tells the story of the life of the Post-Impressionist painter exclusively by means of a cinematic manipulation of his paintings. Overall, the film consists of a masterful succession of 207 shots of paintings, which suggest a continuity that is comparable with a feature film. Just like a filmmaker constructs a scene with shots and an entire film with scenes, Resnais composed his film by means of images of paintings - for the most part these are landscapes, not only because the landscape was Van Gogh's preeminent subject but also because Resnais attempts to evoke a spatial realm inhabited by the artist Van Gogh himself. In order to tell the story of the painter's life, Resnais rearranges dozens of paintings into a kind of storyboard. Constructing links between the individual images, Resnais mobilizes or animates them. He uses several speeds and forms of transitions (from straight cuts to slow overlap dissolves), bringing the static images to life by means of camera movements in all directions. Furthermore, rather than juxtaposing shots of paintings, Resnais confronts parts of paintings to one another. Consequently, Resnais destroyed the spatial integrity of the individual artworks in two ways: by focusing on isolated details on the one hand, and by jumping through an entire oeuvre on the other. In Resnais's film, Van Gogh's complete oeuvre is seen as a single vast painting.

Something similar is at stake in The Open Window (La Fenêtre ouverte, 1952), a film that has the history of landscape painting as its subject. The film was realized by Henri Storck, who had previously made seminal prize-winning documentaries on Paul Delvaux and Rubens. ${ }^{2}$ Shot in Technicolor, The Open Window was an international co-production made as part of a cultural collaboration between the countries that had signed the Brussels Treaty in 1948: France, Great Britain, Belgium, the Netherlands, and Luxembourg. The film opens with a shot of the central panel of a fifteenth-century triptych by the Master of the Magdalene Legend. A forward tracking shot draws our attention to the open window in the upper-right side of the panel, through which a landscape can be seen. Moving from the sacred to the profane, from the interior to the exterior, the rest of the film reconstructs the

2 These are Le Monde de Paul Delvaux (1946) and Rubens (1948, with Paul Haesaerts) (Jacobs 2019a, 23-33). 
history of landscape painting from fifteenth-century Flemish painting up to French Impressionism, using 58 paintings by well-known masters. [Figs. 1-4.] In the process, Storck's camera glides over the details - a critic praised Storck as "a great image-maker for knowing which details in the paintings tell a story" (Forsyth Hardy quoted in Aubenas 1997, 116). But Storck also focuses our attention to the overall coherence of some compositions - such as in the case of Pieter Bruegel's Landscape with the Fall of Icarus (c. 1565), when the camera pulls back and alludes to the opening of new horizons and perspectives. Prefiguring what will later become the conventional art documentary, Storck's camera tracks and dollies over the pictorial surface, mobilizing and animating static paintings.

Storck stated that the crew did "its outmost to completely eliminate the artifices of filming, to conjure away, so to speak, the camera in order to plunge the viewer into the very world of the painting and finally into the landscape that it represents. We want the viewers, through the paintings of artists, to discover for themselves the sentiment of nature" (Debrix n.d.). ${ }^{3}$ Storck, as it were, abolishes the frames of the paintings to enter the frame of cinema, attempting to reconcile the space of a painting with the space of film. For André Bazin, this is why the new art documentaries of the late 1940s and early 1950s were precisely so interesting. According to Bazin (1975), the fixed frame of painting encloses a world that entirely exists by and for itself; it draws the attention in a centripetal way to a static composition. The frame of the film camera, by contrast, is mobile and implies a centrifugal space extending beyond the frame into the smallest and most remote corners of everyday life. When we show a part of a painting on a film screen, the space of the painting loses its orientation and it is presented as something borderless and hence as something that extends beyond the frame. Apart from the (educational or democratizing) fact that cinema is capable of bringing art to wider audiences, film presents a painting as part of the world. According to Bazin, Resnais succeeded precisely in introducing this centrifugal space of film into the centripetal space of painting. By switching between paintings and by letting the camera glide over surfaces the limits of which remain invisible, Resnais breaks through the spatial restraints of painting. In the most exciting of the lyrical art documentaries of the 1940s and 1950s, filmmakers play on this tension, which is inherently connected with the confrontation of both media. Even when using a static shot, facing the painting frontally, due to the differences between the aspect ratio of the film and the proportions of the painting,

3 Jean R. Debrix's article Les peintres paysagistes is quoted on the webpage of the Henri Storck Foundation: https://fondshenristorck.be/en/henri-storck/filmography-hs/films-alphabetically/ the-open-window/. Last accessed 12. 12. 2020. 
the encounter between the frame of the film and the frame of the painting creates a spatial tension - this is what Jean-Marie Straub and Danièlle Huillet, for instance, emphasized in their Visit to the Louvre (Visite au Louvre, 2004), which is marked by highly remarkable asymmetric framings (Jacobs 2018).

While so many filmmakers attempt to present a landscape as a picture, subjecting a site to an image answering to pictorial conventions, documentaries on paintings do the opposite: they willing or nilling present paintings as material things in three-dimensional space. Resnais, Storck, and other filmmakers in the 1940s and 1950s played on this, presenting the art documentary as a platform on which the borders between movement and stasis, the two and three-dimensional, and reality and artificiality could be explored. Since then, many filmmakers and artists have emphasized the spatial ambiguities engendered by the encounter between film and painting. Using various pictorial effects in many of his feature films, Aleksandr Sokurov, for instance, made several essay films dealing with painting, and landscape painting in particular. One of these films deals with Hubert Robert, the eighteenthcentury painter closely connected to the picturesque. In several scenes, Sokurov scans Robert's pictorial surfaces like Resnais and Storck but, with the help of distorted lenses or digital processing, he also creates a waving texture that gives us the feeling that we enter a dream world, a dimension outside time, or that we enter the realm of a painting and the texture of paint. Likewise, in Elegy of a Voyage (Elegiya dorogi, 2001), Sokurov himself plays the part of a nocturnal intruder of the Rotterdam museum, touching the surface of several canvasses. With the help of blurred lenses and forward tracking shots, he conflates real and painted landscapes. This practice of trying to enter the painting also aspires to the aesthetics of the picturesque, which invites us to walk into the view, to dissolve the picture, while this immersion is somehow always thwarted. Filmmakers, too, have attempted to integrate characters into the painted landscape - famous examples are Akira Kurosawa's Dreams (1990 with a segment featuring an art student who finds himself inside the world of Van Gogh's artwork, where he meets the artist (impersonated by Martin Scorsese); or Éric Rohmer's The Lady and the Duke (L'Anglaise et le duc, 2001), in which the actors were filmed superimposed over eighteenth-century scenic paintings.

In various ways, Kurosawa, Rohmer, and Sokurov, like Storck and Resnais, create the illusion that we are getting close to the painting, that we are stepping into it, that we touch it - as Sokurov literally does in his Elegy of a Voyage. The film camera, and especially the moving film camera enables not only an optical but also a haptic confrontation with the painted landscape. Close-ups reveal texture and tactility, but this tactility abstracts the landscape image and focuses our attention on the paint 
and the canvas. In Van Gogh and La Fenêtre ouverte, Resnais and Storck respectively present painted landscapes as something pictorial, in the sense of painterly. Close shots obscure spatial contexts, focusing on cut-outs without a horizon - when there is no horizon, we cannot speak of a landscape. Creating a pictorial intensity, closeups undermine the mimetic coherence of the paintings, evoking what Georges DidiHuberman called the "pan" that is "a symptom of paint within the picture" (2005, 261). Details seem to collapse, crumbling into a pure coloured chaos. The close-up gaze, in the words of Didi-Huberman $(2005,236)$, "manages only to undo matter and form," condemning itself "to a veritable tyranny of the material."

Resnais and Storck's close-ups abstract the image but they make visible the paint in the painting. Resnais's film does not only focus on Van Gogh's insanity, it also emphasizes his nervous brush strokes. In so doing, the art documentaries of Resnais and Storck fully exploit the logics of mechanical reproduction as art theoretical tools. Although the admiration of the bravura brushwork of master painters reaches back for centuries, it was only in the 1930s that photographic close-ups focusing on the application of paint started to appear in art books. Photographs and films were deployed in the discovery and the representation of "painterly effects" - in the modernist, Greenbergian sense -, that is the application of the paint on the canvas, the rhythms of the brushwork, the texture of the canvas, et cetera. In the process, paintings are turned into abstract landscapes - paintscapes. The flat surface of the painting becomes an ambivalent space - not unlike Abstract Expressionist painters who presented their wall-sized all-over structures as abstract landscapes. Paradoxically, the mechanical media of photography and film thus enabled the celebration and even the fetishization of the craftsmanship of the artist and the mastery of the manual, evoking the "impasto" on the surface and the "hand" of the artist.

It should be noted that the abstracting and "paintscaping" qualities of closeups are, of course, not exclusively dependent on a painted landscape in front of a camera. Any object can be transformed into a landscape by means of the magic of close-ups, as demonstrated by Salvador Dali in his Impressions of Upper Mongolia (Impressions de la Haute Mongolie, 1975). This mockumentary about a hunt through Mongolia for a giant hallucinogenic mushroom uses magnified images derived from the metal part of a fountain pen. However, in the case of close-ups of paintings, an additional spatial complexity is invoked. Many artists have used film to explore the ambivalent spaces of close-ups. Marcel Broodthaers, for instance, made several films on paintings. A Voyage on the North Sea (1973-1974) is both a book and a fourminute film (Jacobs 2019b, 257). Only to a certain extent, the book can be presented as a scenario for the film. Likewise, the film can be seen as a documentary on the 
book, demonstrating Broodthaers's lifelong fascination with doubling and with the confrontation between different systems of meaning or communication (word versus image, for instance). Both the book and the film meditate on the appropriation and mechanical reproduction of images and the way a montage of a series of images creates meanings. Strikingly, book and film use an opposite strategy: while the film is organized statically and strictly according to the page numbers, the book is characterized by a dynamic montage of images. The illustrations contain, on the one hand, black-and-white photographs of a small sailboat, and, on the other, colour reproductions of a painting of a seascape with a fishing boat. In various ways, the photographs are juxtaposed with the painting: recreation versus labour, twentieth century versus nineteenth century, reality versus art, black-and-white versus colour. Broodthaers reminds us of the fact that this exploration of the materiality of paint and the fascination of the painterly were highly dependent on mechanical reproductions and hence on the media of film and photography.

It is not a coincidence that Heinrich Wölfflin, who was so important for the link between the eighteenth-century picturesque and the modernist painterly, was one of the first art historians who used slide lectures and who reflected in his writings on the way how mechanical reproductions changed our understanding of art, prefiguring the ideas of Walter Benjamin, André Malraux, and others. ${ }^{4}$ Given this perspective, film is thus in two ways connected with the picturesque. While the picturesque prefigures the motion, duration, and spatialized point-of-view of cinema, film and photography, with the devices of the close-up and montage, contributed to the development of the "painterly." As John Macarthur reminds us, Wölfflin used the word malerisch standing for both "the picturesque" and "the painterly" (Macarthur 2007, 240-247). What's more, Wölfflin investigated the relation between the two different concepts. "The really interesting question now is this," Wölfflin wrote, "what is the relation between the painterly style of treatment and the picturesque quality of the theme?" (Wölfflin 1915, 26). In his later writings, Wölfflin disconnected the picturesque from a specific theme. It became a concept standing first and foremost for something that was characterized by qualities of colour, stroke, and texture rather than of contour and line. In his influential Kunstgeschichtliche Grundbegriffe, das Malerische became an important category, opposing das Lineare or "the linear" (1915, 20-79). Here, the painterly had nothing to do with a naïve taste for charming the views of the poor, becoming an abstract transhistorical category, closely connected to the modernist concept of the painterly.

4 See, for instance, Wölfflin (1896, 224-228; 1897, 294-297; and 1915, 237-244); Wölfflin (1941, 66-81); and Wölfflin 1941, 82-89. See also Adler (2004, 431-456); and Alexander (2018, 79-109). 


\section{References}

Adler, Daniel. 2004. Painterly Politics: Wölfflin, Formalism, and German Academic Culture, 1885-1915. Art History vol. 27, no. 3: 431-456.

Alexander, Zeynep Çelik. 2018. Baroque out of Focus: The Question of Mediation in Wölfflin. New German Critique vol. 45, no. 1 (133): 79-109.

Aubenas, Jaqueline, ed. 1997. Hommage aan Henri Storck: Films 1928-1985. Brussels: Henri Storck Foundation.

Bazin, André. 1975. Peinture et cinéma [Painting and Cinema]. In Qu'est-ce que le cinéma? [What is the Cinema?], 187-192. Paris: Editions du Cerf.

Bertellini, Giorgio. 2009. Italy in Early American Cinema: Race, Landscape, and the Picturesque. Bloomington: Indiana University Press.

Bois, Yve-Alain. 1984. A Picturesque Stroll around Clara-Clara. October no. 29: 32-62.

Choisy, Auguste. 1903. Histoire de l'architecture [A History of Architecture]. Paris: Baranger.

Clarke, David B. and Marcus A. Doel. 2006. From Flatland to Vernacular Relativity: The Genesis of Early English Screenscapes. In Landscape and Film, ed. Martin Lefebvre, 213-244. New York: Routledge.

Collins, Peter. 1965. The Influence of the Picturesque. In Changing Ideals in Modern Architecture, 1750-1950, 42-58. Montreal: McGill-Queen’s University Press.

Cowie, Peter. 2004. John Ford and the American West. New York: Harry N. Abrams. Dalle Vacche, Angela. 1996. Cinema and Painting: How Art Is Used in Film. London: Athlone.

Didi-Huberman, Georges. 2005. Confronting Images: Questioning the Ends of a Certain History of Art. Pennsylvania: Penn State University Press.

Eisenstein, Sergei M. 1989 [1937-1940]. Montage and Architecture (with an introduction by Yve-Alain Bois). Assemblage no. 10 (December): 110-131.

Etlin, Richard. 1987. A Paradoxical Avant-garde. The Architectural Review (January): 21-32.

Hoffmann, Hilmar. 2003. Caspar David Friedrich: Grenzen der Zeit [Caspar David Friedrich: Limits of Time]. In Peter Schamoni: Filmstücke/Film Pieces, ed. Hilmar Hoffmann, 30-41. Stuttgart: Arnoldsche Art Publishers.

Howett, Catherine M. 1997. Where the One-Eyed Man Is King: The Tyranny of Visual and Formalist Values in Evaluating Landscapes. In Understanding Ordinary Landscapes, eds. Paul Groth and Todd W. Bressi, 86-87. New Haven: Yale University Press. 
Hunt, John Dixon. 1976. The Figure in the Landscape: Poetry, Painting, and Gardening During the Eighteenth Century. Baltimore: Johns Hopkins University Press.

Hunt, John Dixon. 1991. Ut Pictura Poesis: The Garden and the Picturesque in England 1710-1750. In The History of Garden Design: The Western Tradition from the Renaissance to the Present Day, eds. Monique Mosser and George Teyssot, 231-241. London: Thames \& Hudson.

Hunt, John Dixon. 1994. Gardens and the Picturesque: Studies in the History of Landscape Architecture. Cambridge, MA: MIT Press.

Hunt, John Dixon and Peter Willis, eds. 1988. The Genius of the Place: The English Landscape Garden 1620-1820. Cambridge, MA: MIT Press.

Hussey, Christopher. 1927. The Picturesque: Studies in a Point of View. London and New York: G. P. Putnam's Sons.

Jacobs, Steven. 2009. The Photoresque: Images between City and Countryside. In Beyond the Picturesque, eds. Steven Jacobs and Frank Maes, 23-64. Ghent: SMAK.

Jacobs, Steven. 2011. Framing Pictures: Film and the Visual Arts. Edinburgh: Edinburgh University Press.

Jacobs, Steven. 2012. Blurring the Boundaries between City and Countryside in Photography. CLCWeb: Comparative Literature and Culture vol. 14, no. 3 (September). http://docs.lib.purdue.edu/clcweb/vol14/iss3/6. Last accessed 17. 08. 2020.

Jacobs, Steven. 2016. Eisenstein's Piranesi and Cinematic Space. In Aspects of Piranesi: Essays on History, Criticism and Invention, eds. Dirk De Meyer, Bart Verschaffel and Pieter-Jan Cierkens, 142-159. Ghent: A\&S/books.

Jacobs, Steven. 2018. Double visite au Louvre: Les explorations muséales de Philibert et de Straub-Huillet [Double Visit to the Louvre: The Museum Explorations of Philibert and Straub-Huillet]. In Muséoscopies: Fictions du musée au cinema [Museoscopies: Fictions from Museum to Cinema], eds. Joséphine Jibokji, Barbara Le Maître, Natacha Pernac and Jennifer Verraes, 45-59. Paris: Presses Universitaires de Paris Nanterre.

Jacobs, Steven. 2019a. Henri Storck's Le Monde de Paul Delvaux and Pygmalionist Cinema. In Documenting the Visual Arts, ed. Roger Hallas, 23-33. New York: Routledge.

Jacobs, Steven. 2019b. A Voyage on the North Sea, Marcel Broodthaers. In Photobook Belge, 1854-Now, ed. Tamara Berghmans, 257-257. Antwerp / Veurne: FoMu / Hannibal. 
Kolen, Jan and Ton Lemaire, eds. 1999. Landschap in meervoud: Perspectieven op het Nederlandse landschap in de 20ste/21ste eeuw [Landscape in Plural: Perspectives on the Dutch Landscape in the 20th/21st Century]. Utrecht: Uitgeverij Jan van Atkel.

Macarthur, John. 2007. The Picturesque: Architecture, Disgust and Other Irregularities. New York: Routledge.

Maillet, Arnaud. 2004. The Claude Glass: Use and Meaning of the Black Mirror in Western Art. New York: Zone Books.

Moholy-Nagy, László. 1995 (1942). Space-Time and the Photographer. In Poetics of Space: A Critical Photographic Anthology, ed. Steve Yates, 145-155. Albuquerque: University of New Mexico Press.

Montani, Pietro. 2000. The Uncrossable Threshold: The Relation of Painting and Cinema in Eisenstein. In The Visual Turn: Classical Film Theory and Art History, ed. Angela Dalle Vacche, 206-217. New Brunswick, NJ: Rutgers University Press.

Schmarsow, August. 1897. Barock Und Rokoko: Eine kritische Auseinandersetzung über das Malerische in der Architektur [Baroque and Rococo: A Critical Examination of the Picturesque in Architecture]. Leipzig: Hirzel.

Smuda, Manfred. 1986. Natur als ästhetischer Gegenstand und als Gegenstand der Ästhetik: Zur Konstitution von Landschaft [Nature as an Aesthetic Object and as an Object of Aesthetics: On the Constitution of Landscape]. In Landschaft [Landscape], ed. Manfred Smuda, 64-65. Franfurt a/M: Suhrkamp.

Tobey, George B. 1973. A History of Landscape Architecture: The Relationship of People to Environment. New York: American Elsevier Publishing Company.

Wölfflin, Heinrich. 1888. Renaissance und Barock: Eine Untersuchung über Wesen und Entstehung des Barockstils in Italien [Renaissance and Baroque: An Inquiry into the Nature and Origin of the Baroque Style in Italy]. München: F. Bruckmann. Wölfflin, Heinrich. Wie man Skulpturen aufnehmen soll. [How to Record Sculptures]. Zeitschrift für Bildende Kunst vol. 7 (1896): 224-228; vol. 8 (1897): 294-297; vol. 26 (1915): 237-244.

Wölfflin, Heinrich. 1915. Kunstgeschichtliche Grundbegriffe: Das Problem der Stilentwicklung in der neueren Kunst [Basic Concepts Of Art History: The Problem of Style Development in Modern Art]. München: Bruckmann.

Wölfflin, Heinrich. 1941. Gedanken zur Kunstgeschichte: Gedrucktes und Ungedrucktes [Thoughts on Art History: the Printed and the Unprinted]. Basel: Benno Schwabe Verlag.

Wölfflin, Heinrich. 1999. Prolegomena zu Einer Psychologie der Architektur [Prolegomena to a Psychology of Architecture]. Berlin: Mann. 


\section{List of Figures}

Figures 1-4. Details of paintings in The Open Window (La Fenêtre ouverte, 1952).
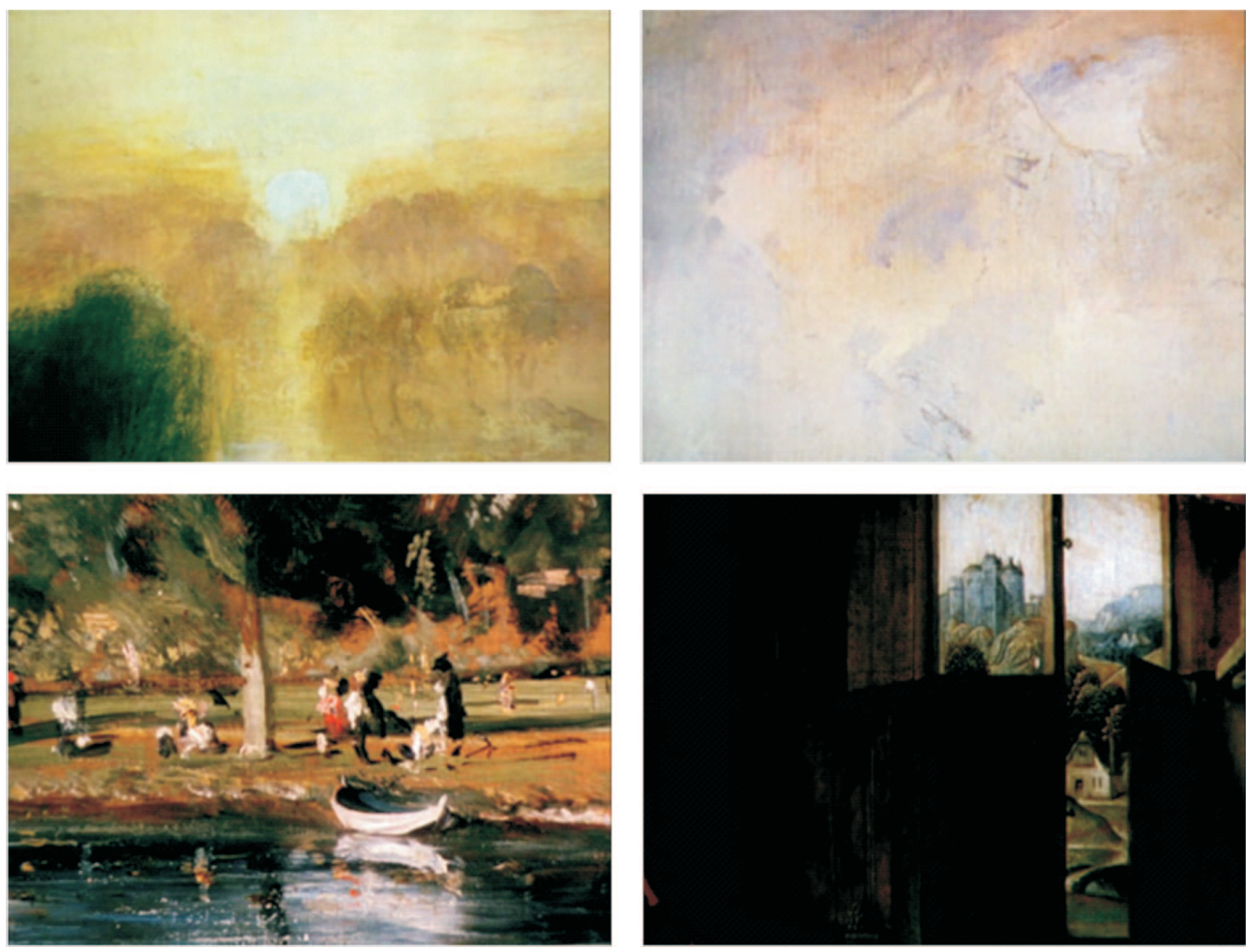